\title{
DEVELOPMENT AND VALIDATION OF RAPID STABILITY-INDICATING HIGH-PERFORMANCE LIQUID CHROMATOGRAPHY METHOD FOR THE DETERMINATION OF LINAGLIPTIN AND EMPAGLIFLOZIN IN PURE AND DOSAGE FORMS
}

\author{
RAGAA EL SHEIKH ${ }^{1}$, WAFAA S HASSAN ${ }^{2}$, EMANH YOUSSEF ${ }^{1}$, ABDULRAHMAN Y HAMDI ${ }^{3}$, \\ NAIF AHMED BADAHDAH ${ }^{3}$, MUNEER ESA ALZUHIRI ${ }^{3}$, AYMAN ABOU ELFETOUH GOUDA ${ }^{1,4 *}$
}

\begin{abstract}
${ }^{1}$ Department of Chemistry, Faculty of Science, Zagazig University, Zagazig, 44519, Egypt. ${ }^{2}$ Department of Pharmaceutical Analytical Chemistry, Faculty of Pharmacy, Zagazig University, Zagazig, Egypt. ${ }^{3}$ Poison control and Medical Forensic Chemistry Center, Makkah, Saudi Arabia. ${ }^{4}$ Department of Faculty of Public Health and Health Informatics, Umm AL-Qura University, Makkah, Saudi Arabia. Email: aymangouda77@gmail.com
\end{abstract}

Received: 28 January 2020, Revised and Accepted: 26 February 2020

\section{ABSTRACT}

Objective: A new, simple, rapid, sensitive, and accurate stability-indicating high-performance liquid chromatography (HPLC) method was developed and validated for the quantitative determination of linagliptin (LNG) and empagliflozin (EMP) in pure and tablet dosage forms.

Methods: An isocratic HPLC method, using a $\mathrm{C}_{18}$ reversed-phase column (150 $\mathrm{mm} \times 4.6 \mathrm{~mm}$ i.d., particle size $\left.5 \mu \mathrm{m}\right)$ with an isocratic binary mobile phase consisting of phosphate buffer and acetonitrile $(65: 35, \mathrm{v} / \mathrm{v})$, was investigated to separate the drug from its stress degradation products. The flow rate was $1.0 \mathrm{~mL} / \mathrm{min}$ at ambient temperature and photodiode array detector is used at $226 \mathrm{~nm}$ for detection. The developed method was validated for system suitability, linearity, accuracy, precision, limits of detection and quantitation, specificity, stability, and robustness.

Results: The retention time of LNG and EMP was found to be $3.276 \pm 0.002$ and $6.966 \pm 0.0006$ min, respectively. The calibration curve was found to be linear with the equation $y=158926.39 X+11.139$, with a correlation coefficient of $R^{2}=0.9991$ for $L N G$ and $y=22688.45 X+4.259$, with a correlation coefficient of $\mathrm{R}^{2}=0.9994$ for EMP over a concentration range of $2.5-7.5 \mu \mathrm{g} / \mathrm{mL}$ and $5.0-15 \mu \mathrm{g} / \mathrm{mL}$ for LNG and EMP, respectively. The limits of detection were 0.29 and $0.48 \mu \mathrm{g} / \mathrm{mL}$ for LNG and EMP, respectively, and the limits of quantification were 0.89 and $1.5 \mu \mathrm{g} / \mathrm{mL}$ for LNG and EMP, respectively. The recovery values of this method are $101.11 \%$ and $101.48 \%$ for LNG and EMP, respectively, and the reproducibility is within 0.070 and 0.277 for LNG and EMP, respectively.

Conclusion: The proposed method is a rapid stability-indicating HPLC method that can be applied for the determination of LNG and EMP in pure and tablet dosage forms.

Keywords: Linagliptin, Empagliflozin, Rapid stability-indicating high-performance liquid chromatography method, Method validation, Dosage forms. (c) 2020 The Authors. Published by Innovare Academic Sciences Pvt Ltd. This is an open access article under the CC BY license (http://creativecommons. org/licenses/by/4. 0/) DOI: http://dx.doi.org/10.22159/ajpcr.2020.v13i4.36939

\section{INTRODUCTION}

Linagliptin (LNG) is a more potent dipeptidyl peptidase (DPP)-4 inhibitor than other drugs that belong to the same class for the treatment of Type II diabetes. LNG is a competitive and reversible DPP-4 enzyme inhibitor that slows the breakdown of insulinotropic hormone glucagon-like peptide- 1 for better glycemic control in diabetes patients. Empagliflozin (EMP) is a sodium glucose cotransporter-2 inhibitor indicated as an adjunct to diet and exercise to improve glycemic control in adult patients with Type 2 diabetes. The combination of LNG and EMPis served as an adjuvant to diet and exercise to improve glycemia control in adults with Type-2 diabetes who know to have the cardiovascular disease [1-3].LNGchemically,8-[(3R)-3-aminopiperidin-yl]-7-(but-2yn-1-yl)-3methyl-1-[(4-methyl quinazolin-2-yl)methyl]3,7-dihydro-1H-purine-2,6-dione.EMP, chemically designated as $(2 \mathrm{~S}, 3 \mathrm{R}, 4 \mathrm{R}, 5 \mathrm{~S}, 6 \mathrm{R})-2$ - [4-chloro-3-(\{4-[(3S)-oxolan-3-yl ox y]ph enyl\} methyl)phenyl]-6-(hydroxymethyl)oxane-3,4,5-triol (Fig. hjterature review revealed that few methods were described for the determination of LNG and EMP alone or in combination with other drugs from pharmaceutical dosage forms and in human plasma including spectrophotometry [4-7], ultra-performance liquid chromatography (LC) [8], LC-mass spectroscopy [9], and high-performance LC (HPLC) [10-25] techniques.
The aim of the present work is to develop and validate simple, fast, and reliable stability-indicating reverse-phase HPLC method with ultraviolet (UV) detection for the simultaneous determination of LNG and EMP in pure and pharmaceutical dosage forms. The proposed method can overcome the problems in all previously reported HPLC methods such as long time of analysis and expensive detectors, as shown in Table 1

\section{METHODS}

Instrumentation

HPLC apparatus (Agilent 1200, Agilent, USA) equipped with UV detector DAD system. The $\mathrm{pH}$ measurements were made on a Hanna $\mathrm{pH}$ meter equipped with a combined glass-calomel electrode (Portugal) (HI: 9321).

Chemicals and reagents

Analytical HPLC grade solvents were used in all experiments, including acetonitrile and methanol (LAB-SCAN, Analytical Sciences, Gliwice, UL, Sowinskiego, Poland). Potassium dihydrogen orthophosphate, sodium hydroxide $(\mathrm{NaOH})$, hydrochloric acid $(\mathrm{HCl})$, and hydrogen peroxide $\left(\mathrm{H}_{2} \mathrm{O}_{2} 30 \%, \mathrm{v} / \mathrm{v}\right)$ were purchased from Sigma-Aldrich (St. Louis, MO, USA). Double distilled water was used.

LNG (99.40\%) and EMP (99.70\%) were kindly supplied by Zeta Pharma, Egypt. The pharmaceutical dosage forms used were Glyxambi tablets (Eli Lilly and Company; Boehringer Ingelheim Pharmaceuticals, Inc., 
Table 1: Chromatographic methods reported for the determination of LNG and EMP in dosage forms

\begin{tabular}{|c|c|c|c|c|c|c|c|}
\hline \multicolumn{3}{|l|}{ Chromatographic conditions } & \multicolumn{2}{|c|}{$\operatorname{LOD}(\mu \mathrm{g} / \mathrm{mL})$} & \multicolumn{2}{|c|}{$\begin{array}{l}\text { Concentration range } \\
(\mu \mathrm{g} / \mathrm{mL})\end{array}$} & \multirow[t]{2}{*}{ References } \\
\hline Mobile phase & $\begin{array}{l}\text { Flow rate } \\
(\mathrm{mL} / \mathrm{min})\end{array}$ & $\begin{array}{l}\text { Detection } \\
\text { (UV at) (nm) }\end{array}$ & LNG & EMP & LNG & EMP & \\
\hline Phosphoric acid:acetonitrile (45:50, v/v) & 1.0 & 245 & - & - & $12.5-75$ & $25-150$ & [19] \\
\hline $0.1 \%$ perchloric acid:acetonitrile $(60: 40, \mathrm{v} / \mathrm{v})$ & 1.0 & 230 & 0.43 & 0.03 & $12.5-75$ & $12.5-75$ & [20] \\
\hline $\begin{array}{l}0.1 \% \text { phosphoric acid }(\mathrm{pH} 4.5) \text { :acetonitrile } \\
(68: 32, \mathrm{v} / \mathrm{v})\end{array}$ & 1.0 & 218 & & & $0.01-10$ & $0.01-10$ & [12] \\
\hline $\begin{array}{l}\text { Methanol:phosphate buffer }\left(\mathrm{KH}_{2} \mathrm{PO}_{4}, \mathrm{~K}_{2} \mathrm{HPO}_{4}\right) \\
(\mathrm{pH} 3.0)(70: 30, \mathrm{v} / \mathrm{v})\end{array}$ & 1.0 & 254 & 0.0372 & 2.17 & $20-1000$ & $10-50$ & [21] \\
\hline $\begin{array}{l}\text { Methanol:acetonitrile: } 0.1 \% \text { ortho phosphoric } \\
\text { acid }(30: 60: 10, v / v)\end{array}$ & 1.0 & 246 & 0.03 & 0.06 & $2.5-15$ & $5.0-30$ & [22] \\
\hline $\begin{array}{l}\text { Potassium dihydrogen phosphate buffer } \mathrm{pH} \\
\text { (3.4):methanol }(70: 30, \mathrm{v} / \mathrm{v})\end{array}$ & 1.0 & 240 & 0.39 & 0.76 & $50-150$ & $50-150$ & [23] \\
\hline $\begin{array}{l}\text { Phosphate buffer } 0.01 \text { M:acetonitrile (65:35, } \\
\text { v/v) }\end{array}$ & 1.0 & 226 & 0.29 & 0.48 & $2.5-7.5$ & $5.0-15$ & $\begin{array}{l}\text { Proposed } \\
\text { work }\end{array}$ \\
\hline
\end{tabular}

LNG: Linagliptin, EMP: Empagliflozin, LOD: Limit of detection

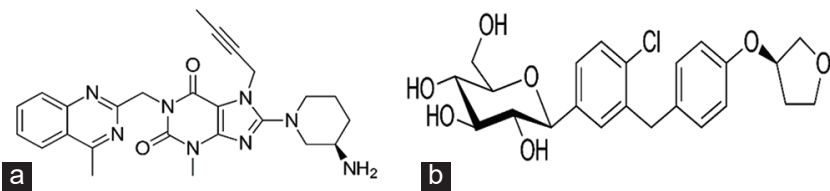

Fig. 1: The chemical structure of (a) linagliptin and (b) empagliflozin

$5.0 \mathrm{mg} \mathrm{LNG}$ and $10 \mathrm{mg}$ EMP per tablet) and Empacoza plus tablets (Zeta Pharma, Egypt, $5.0 \mathrm{mg}$ LNG and $10 \mathrm{mg}$ EMP per tablet).

\section{Chromatographic conditions}

The chromatographic separation was performed using ODS-3 InertsilC18 (150 $\mathrm{mm} \times 4.6 \mathrm{~mm}), 5.0 \mu \mathrm{m}$ particle size column; the column temperature was maintained at $25 \pm 2^{\circ} \mathrm{C}$. The autosampler utilized methanol as a rinse solution, the total run time was $6.0 \mathrm{~min}$. The elution quaternary pump ran an isocratic flow using mobile phase consisting of a mixture of phosphate buffer and acetonitrile $(65: 35, \mathrm{v} / \mathrm{v})$ at a flow rate of $1.0 \mathrm{~mL} / \mathrm{min}$. The eluate was monitored at $226 \mathrm{~nm}$ using UV diode array detector. The retention time of the drug was found to be LNG and EMP which were found to be $3.276 \pm 0.002$ and $6.966 \pm 0.0006 \mathrm{~min}$, respectively. The injection volume was $20 \mu \mathrm{L}$. Mobile phase was used as diluent during the standard and test samples preparation.

\section{Preparation of standard solutions}

A stock solution of LNG or EMP $(10 \mu \mathrm{g} / \mathrm{mL})$ was prepared by dissolving $10 \mathrm{mg}$ of LNG and EMP in mobile phase in $100 \mathrm{~mL}$ volumetric flask, then shaken and sonicated for 10 min till completely dissolved and then complete the volume to $100 \mathrm{~mL}$ with mobile phase. The working standard solutions were prepared by diluting aliquots of stock solution with mobile phase to obtain final concentrations ranging from 2.5-7.5 $\mu \mathrm{g} / \mathrm{mL}$ to $5.0-15 \mu \mathrm{g} / \mathrm{mL}$ for $\mathrm{LNG}$ and EMP, respectively. Working solutions of the drugs were stable for 1 week.

\section{Construction of calibration curves}

Aliquots of standard solution, ranging from $2.5-7.5 \mu \mathrm{g} / \mathrm{mL}$ to $5.0-15 \mu \mathrm{g} / \mathrm{mL}$ for LNG and EMP, respectively, were prepared in a series of $10 \mathrm{~mL}$ volumetric flasks, $20 \mu \mathrm{L}$ were injected into the instrument. Detection was performed at the wavelength of $226 \mathrm{~nm}$. The calibration graph was constructed by plotting the peak areas obtained at the wavelength of $226 \mathrm{~nm}$ versus the corresponding injected concentrations.

\section{Assay for tablets dosage forms}

Twenty tablets of Glyxambi and Empacoza plus were weighed, finely powdered, and an accurately weighed amount of the powdered tablets equivalent to $5.0 \mathrm{mg} \mathrm{LNG}$ and $10 \mathrm{mg}$ EMP which were transferred to
Table 2: System suitability and statistical analysis

\begin{tabular}{|c|c|c|}
\hline Parameters & LNG & EMP \\
\hline \multicolumn{3}{|l|}{ System suitability } \\
\hline $\mathrm{t}_{\mathrm{p}} \pm \mathrm{SD}(\mathrm{min})$ & $3.276 \pm 0.002$ & $6.966 \pm 0.0006$ \\
\hline $\begin{array}{l}\text { Number of theoretical } \\
\text { plates (n) }\end{array}$ & 6687 & 11895 \\
\hline $\mathrm{k}^{\prime}$ & 0.219 & 1.590 \\
\hline \multicolumn{3}{|c|}{ Linearity and regression data } \\
\hline Linearity range $(\mu \mathrm{g} / \mathrm{mL})$ & $2.5-7.5$ & $5.0-15$ \\
\hline $\begin{array}{l}\text { Limit of detection } \\
(\mu \mathrm{g} / \mathrm{mL})\end{array}$ & 0.29 & 0.48 \\
\hline $\begin{array}{l}\text { Limit of quantitation } \\
(\mu \mathrm{g} / \mathrm{mL})\end{array}$ & 0.89 & 1.50 \\
\hline Slope (b) $\pm R S D$ & $158926.39 \pm 0.362$ & $22688.45 \pm 0.451$ \\
\hline Intercept (a) \pm RSD & $11.139 \pm 0.708$ & $4.259 \pm 0.824$ \\
\hline Correlation coefficient $\left(\mathrm{R}^{2}\right)$ & 0.9991 & 0.9994 \\
\hline \multicolumn{3}{|c|}{ Comparison with a reported method [20] } \\
\hline$t$-test ${ }^{a}$ & 0.116 & 0.196 \\
\hline F-ratio ${ }^{a}$ & 1.536 & 1.818 \\
\hline
\end{tabular}

${ }^{\mathrm{a}}$ Theoretical value for $\mathrm{t}$ and $\mathrm{f}$ at confidence limit at $95 \%$ confidence level and five degrees of freedom $(\mathrm{p}=0.05)$ are 2.571 and 5.05, respectively, SD: Standard deviation, RSD: Relative standard deviation

$100 \mathrm{~mL}$ measuring flask and dissolved in $50 \mathrm{~mL}$ of mobile phase, sonicated for $10 \mathrm{~min}$, and the solution was filtered through a $0.45 \mu \mathrm{m}$ membrane filter and then the final solution was completed to volume with mobile phase. The proposed procedure was then completed as mentioned above.

\section{RESULTS}

\section{DISCUSSION}

\section{Method optimization}

The conditions affecting the chromatographic performance of LNG and EMP were carefully studied to recognize the most suitable chromatographic system. Hence, the optimum chromatographic performances were achieved when using isocratic mobile phase composed of phosphate buffer and acetonitrile $(65: 35, \mathrm{v} / \mathrm{v})$ with a flow rate of $1.0 \mathrm{~mL} / \mathrm{min}$, injection volume $20 \mu \mathrm{L}$, column temperature $25^{\circ} \mathrm{C}$, and detection wavelength $226 \mathrm{~nm}$. The results of three runs indicate high system suitability (Table 2). The retention time $\left(t_{R}\right)$ values $L N G$ and EMP were found to be $3.276 \pm 0.002$ and 6.966 $\pm 0.0006 \mathrm{~min}$, respectively (Fig. 2).

\section{Method validation}

The developed method was validated for system suitability, linearity, sensitivity, precision, accuracy, robustness selectivity, and 


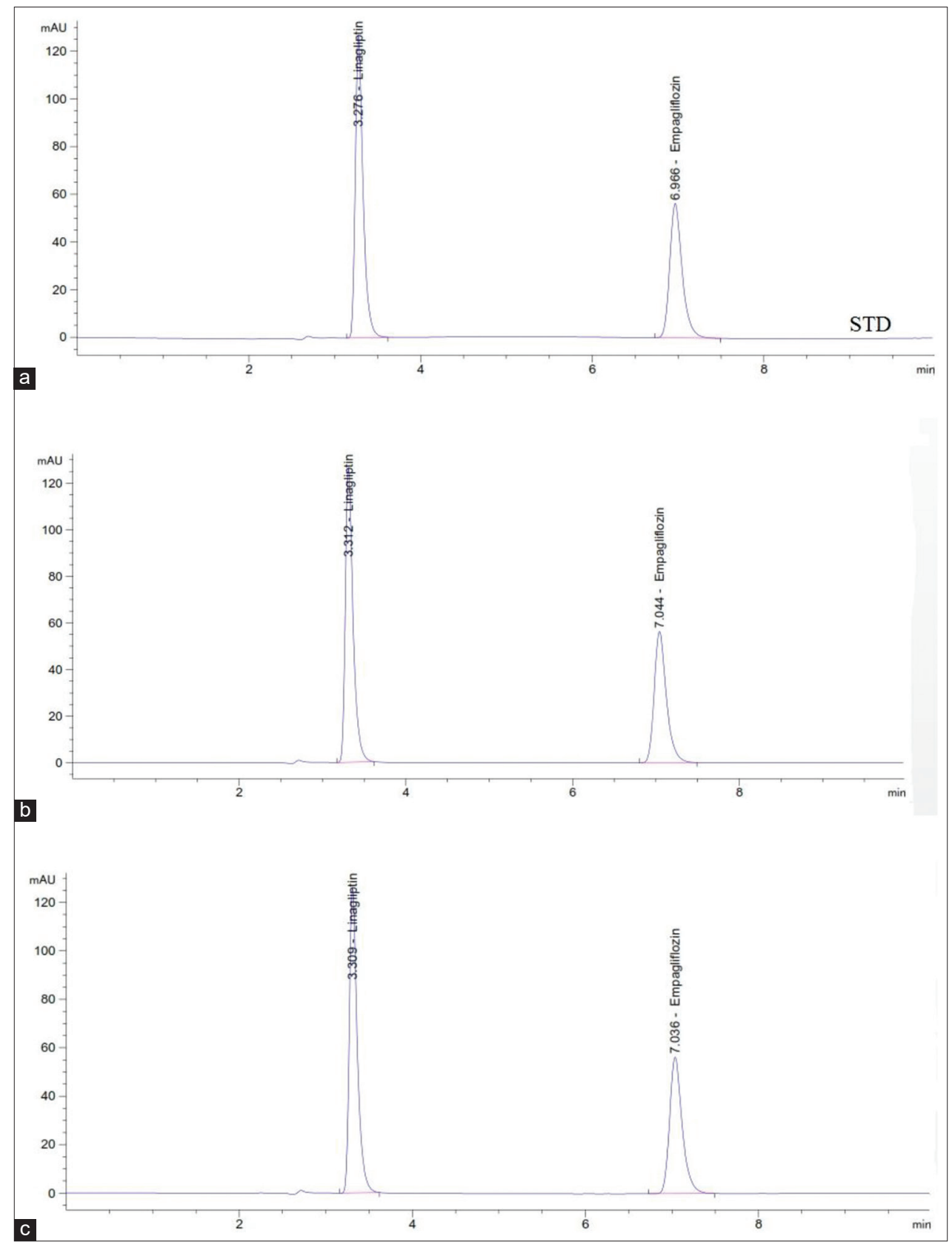

Fig. 2: Chromatogram of linagliptin and empagliflozin from (a) raw material, (b) Empacoza plus tablet, and (c) Glyxambi tablet

specificity and is applied for forced degradation studies as per the ICH guidelines [26].

\section{Linearity}

The linearity of LNG and EMP was established by eight-point calibration curve, concentration ranging from 2.5 to $7.5 \mu \mathrm{g} / \mathrm{mL}$ and 5.0 to $15 \mu \mathrm{g} / \mathrm{mL}$ for LNG and EMP, respectively. The graph of the peak area against concentration proved linear graph with regression equations; $y=158,926.39 x+11.139$ and $y=22,688.45 x+4.259$, with a correlation coefficients $\left(R^{2}=0.9991\right.$ and 0.9994$)$ for $L N G$ and EMP, respectively.

\section{Sensitivity}

The limit of detection is defined as the injected quantity giving $\mathrm{S}=\mathrm{N}$ of 3 (in terms of peak area) and were found to be 0.29 and $0.48 \mu \mathrm{g} / \mathrm{mL}$ for LNG and EMP, respectively. The limit of quantification is defined as the injected quantity giving $\mathrm{S}=\mathrm{N}$ of 10 (in terms of peak area) and was found to be 0.89 and $1.50 \mu \mathrm{g} / \mathrm{mL}$ for LNG and EMP, respectively (Table 2).

\section{Precision}

The intraday repeatability (precision) of the developed method was assessed by analyzing six replicate injections of the standard solution at three different concentrations on the same day. The same was done for interday precision test except that the injection of the samples was every day for 5 days. The precision of the method was determined by calculating relative standard deviation (RSD \%). The results in Table 3 show that the method is reproducible and there were high intra- and inter-day precisions ( $\mathrm{RSD} \leq 0.435 \%$ ).

\section{Accuracy}

Accuracy of the method was established by performing recovery studies according to the ICH guidelines. Spiked samples were prepared by spiking pre-analyzed sample solutions with standard drug at three different concentration levels $(50 \%, 100 \%$, and $150 \%$ level). Mean percentage recovery values at three different concentrations of the two drugs were calculated. The \% mean recovery was ranged from 100.13 to $101.20 \%$ and 100.40 to $101.70 \%$ for LNG and EMP, respectively (Table 3 ). 


\section{Robustness}

The robustness of the present method was evaluated in terms of temperature, flow rate, column to column, wavelength of detection, and injection volume (Table 4). The slight variations in the examined factors had no significant effect on the shape of the peak. The results of coefficient of variation \% indicate that the method is more sensitive to changes in the wavelength and the flow rate greater than to changes in the other factors. Compared with retention times ( $\mathrm{t}_{\mathrm{R}}$-values), peak areas were more affected with the slight changes in the chromatographic conditions.

\section{Selectivity and specificity of the method}

The resulted peak after tablet analysis is found to be homogeneous and there are no coeluting peaks indicating specificity of the method. Comparison between the chromatogram of the raw LNG and EMP and that of extracted LNG and EMP from tablets indicate that the excipients in the formulation did not interfere with the determination of LNG and EMP.

\section{Accuracy and application}

Analysis of LNG and EMP in Empacoza plus and Glyxambi tablets by the proposed method showed high accuracy with a mean recovery range of $100.71 \pm 0.541 \%$ and $100.81 \pm 0.589 \%$ and $101.48 \pm 0.254 \%$ and $101.64 \pm 0.289 \%$ for LNG and EMP, respectively (Table 5). The results were compared with a reported method [20]. The values of $t$ and $f$ indicate that there is no significant difference between both methods.

\section{Stability tests}

The results (Fig. 3) of stress degradation indicate that LNG and EMP are strongly affected with reflux with $\mathrm{HCl}$ or $\mathrm{NaOH}$. Reflux with $\mathrm{H}_{2} \mathrm{O}_{2}$ and

Table 3: Intra- and interday precision and accuracy of LNG and EMP ( $n=5)$

\begin{tabular}{|c|c|c|c|c|c|c|}
\hline \multirow[t]{2}{*}{ Injected amount $(\mu \mathrm{g} / \mathrm{mL})$} & \multicolumn{3}{|l|}{ Intraday } & \multicolumn{3}{|l|}{ Interday } \\
\hline & $\begin{array}{l}\text { Observed } \\
\text { amount } \pm S D\end{array}$ & RSD \%* & $\begin{array}{l}\text { Accuracy } \\
(\text { recovery \%)** }\end{array}$ & $\begin{array}{l}\text { Observed } \\
\text { amount } \pm S D\end{array}$ & RSD \%* & $\begin{array}{l}\text { Accuracy } \\
\text { (recovery \%)** }\end{array}$ \\
\hline 2.5 & $2.53 \pm 0.003$ & 0.119 & 101.20 & $2.52 \pm 0.004$ & 0.159 & 100.80 \\
\hline 5 & $5.05 \pm 0.003$ & 0.059 & 101.0 & $5.01 \pm 0.002$ & 0.040 & 100.20 \\
\hline 7.5 & $7.58 \pm 0.033$ & 0.435 & 101.07 & $7.51 \pm 0.013$ & 0.173 & 100.13 \\
\hline \multicolumn{7}{|l|}{ EMP } \\
\hline 5 & $5.06 \pm 0.007$ & 0.138 & 101.20 & $5.02 \pm 0.011$ & 0.219 & 100.40 \\
\hline 10 & $10.17 \pm 0.003$ & 0.029 & 101.70 & $10.08 \pm 0.015$ & 0.149 & 100.80 \\
\hline 15 & $15.23 \pm 0.016$ & 0.105 & 101.56 & $15.11 \pm 0.01$ & 0.066 & 100.73 \\
\hline
\end{tabular}

${ }^{*}$ RSD $(\%)=S D \times 100 /$ mean. ${ }^{* *}$ Accuracy (recovery \%)=(Observed amount/Injected amount) $\times 100$. SD: Standard deviation, RSD: Relative standard deviation, LNG: Linagliptin, EMP: Empagliflozin

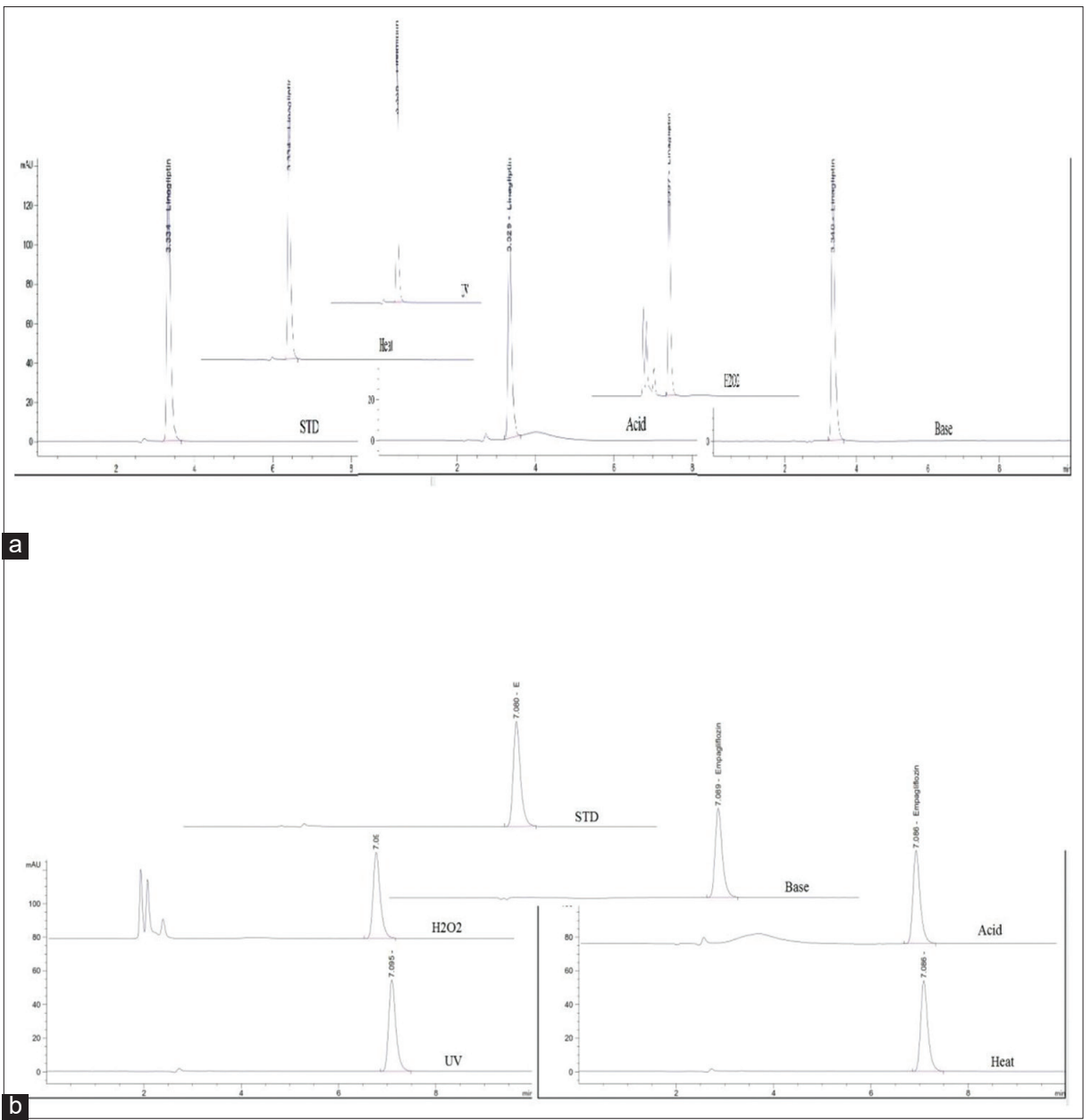

Fig. 3: Separation of (a) linagliptin and (b) empagliflozin from degradants after stress conditions 
Table 4: Robustness of the proposed method

\begin{tabular}{|c|c|c|c|c|c|c|c|c|c|c|}
\hline \multirow{2}{*}{$\begin{array}{l}\text { Changes factors } \\
\text { LNG }\end{array}$} & \multicolumn{2}{|l|}{ Temp. $\left({ }^{\circ} \mathrm{C}\right)$} & \multicolumn{2}{|c|}{$\begin{array}{l}\text { Flow rate } \\
(\mathrm{mL} / \mathrm{min})\end{array}$} & \multicolumn{2}{|c|}{ Column to column } & \multicolumn{2}{|c|}{$\begin{array}{l}\text { Wavelength of } \\
\text { detection }(\mathrm{nm})\end{array}$} & \multicolumn{2}{|c|}{ Injected volume $(\mu \mathrm{L})$} \\
\hline & & & & & & & & & & \\
\hline Changes & \multicolumn{2}{|l|}{23,25 , and 27} & \multicolumn{2}{|c|}{$0.95,1.0$, and 1.05} & \multicolumn{2}{|l|}{ ODS-3V, ODS } & \multicolumn{2}{|c|}{224,226 , and 228} & \multicolumn{2}{|c|}{$19.9,20$, and 20.1} \\
\hline Tested parameter & Peak area & $t_{R}$ & Peak area & $t_{R}$ & Peak area & $t_{R}$ & Peak area & $t_{R}$ & Peak area & \\
\hline $\mathrm{CV}(\%)$ & 0.125 & 0.51 & 0.131 & 0.98 & 0.039 & 0.33 & 0.864 & 0.82 & 0.453 & 0.73 \\
\hline \multicolumn{11}{|l|}{ EMP } \\
\hline Changes & 23,25 , and 27 & & $0.95,1.0, \mathrm{a}$ & .05 & ODS-3V, ODS & & 224,226 , a & 28 & $19.9,20, \mathrm{a}$ & \\
\hline $\begin{array}{l}\text { Tested parameter } \\
\text { CV (\%) }\end{array}$ & $\begin{array}{l}\text { Peak area } \\
0.502\end{array}$ & $\begin{array}{l}\mathrm{t}_{\mathrm{R}} \\
0.47\end{array}$ & $\begin{array}{l}\text { Peak area } \\
0.228\end{array}$ & $\begin{array}{l}\mathrm{t}_{\mathrm{R}} \\
0.67\end{array}$ & $\begin{array}{l}\text { Peak area } \\
0.095\end{array}$ & $\begin{array}{l}\mathrm{t}_{\mathrm{R}} \\
0.29\end{array}$ & $\begin{array}{l}\text { Peak area } \\
0.917\end{array}$ & $\begin{array}{l}\mathrm{t}_{\mathrm{R}} \\
0.87\end{array}$ & $\begin{array}{l}\text { Peak area } \\
0.508\end{array}$ & $\begin{array}{l}\mathrm{t}_{\mathrm{R}} \\
0.65\end{array}$ \\
\hline
\end{tabular}

LNG: Linagliptin, EMP: Empagliflozin, CV: Coefficient of variation

Table 5: Statistical analysis of results obtained by the proposed method applied on tablets compared with a reported method

\begin{tabular}{|c|c|c|c|c|c|c|}
\hline & \multicolumn{3}{|l|}{ LNG } & \multicolumn{3}{|l|}{ EMP } \\
\hline & \multirow{2}{*}{$\begin{array}{l}\text { Proposed method } \\
\text { Empacoza plus tablets }\end{array}$} & \multicolumn{2}{|c|}{ Reported method [20] } & \multicolumn{2}{|l|}{ Proposed method } & \multirow[t]{2}{*}{ Reported method [20] } \\
\hline & & Glyxam & & Empacoza plus tablets & Glyxambi tablets & \\
\hline Mean recovery ${ }^{\mathrm{a}}$ & 100.71 & 100.81 & 100.52 & 101.48 & 101.64 & 101.29 \\
\hline$\pm \mathrm{SD}$ & 0.541 & 0.589 & \pm 0.545 & 0.254 & 0.214 & \pm 0.289 \\
\hline$\pm \mathrm{RSD} \%$ & 0.537 & 0.584 & \pm 0.542 & 0.251 & 0.210 & \pm 0.286 \\
\hline Variance & 0.292 & 0.346 & 0.297 & 0.065 & 0.046 & 0.084 \\
\hline SE & 0.242 & 0.263 & 0.242 & 0.114 & 0.096 & 0.129 \\
\hline $\mathrm{t}$-value ${ }^{\mathrm{b}}$ & 0.150 & 0.212 & & 0.547 & 1.146 & \\
\hline F-value ${ }^{b}$ & 1.014 & 0.856 & & 1.296 & 1.845 & \\
\hline
\end{tabular}

${ }^{\mathrm{a}}$ Average of five determinations $(\mathrm{n}=5) .{ }^{\mathrm{b}}$ Theoretical values for $\mathrm{t}$ and $\mathrm{f}$ at confidence limit at $95 \%$ confidence level and five degrees of freedom ( $\left.\mathrm{p}=0.05\right)$ are 2.776 and 6.39 , respectively

exposure to UV radiation leads to degradation of EMP and LIN, but the effect here is weaker than that in the case of $\mathrm{HCl}$ and $\mathrm{NaOH}$. There is no interference with the peak of the intact drug, indicating that the method is stability indicating (Fig. 3). Hence, the proposed analytical method is also useful for the determination of LNG and EMP stability in sample of pharmaceutical dosage form.

\section{CONCLUSION}

Precise, simple, accurate, robust, and cost-effective stability-indicating HPLC method was developed for the routine and quantification analysis of LNG and EMP in pure forms and tablets. The method was successfully validated in terms of linearity, precision, and accuracy as per the ICH guidelines. Compared with the published chromatographic methods, this method represents a strong reduction of the analysis time and it is considered as a stability-indicating method. A high recovery of LNG and EMP in tablets was achieved. The proposed method ensured a precise and accurate determination of LNG and EMP in tablet formulations and is a stabilityindicating method. No interference from the excipients was noticed. Hence, it can be concluded that the proposed method was a good approach for obtaining reliable results and found to be suitable for the routine analysis and quality control and percentage degradation of pharmaceutical preparations containing both drugs either individually or in combination.

\section{AUTHORS' CONTRIBUTIONS}

Prof. Dr. Ragaa El Sheikh has generated the research idea and interpreted the data and helped to draft the manuscript. Prof. Dr. Wafaa El Sayed Hassan has suggested the research idea and participated in the design of the study. Miss. Eman Helmy Youssef was prepared the solutions, carried out the experiments, interpreted the data, and helped to draft the manuscript. Dr. Abdulrahman Y. Hamdi has suggested the research idea and participated in the design of the study. Mr. Naif Ahmed Badahdah has participated in the design of the study and carried out the experiments. Mr. Muneer Esa Alzuhiri has participated in the design of the study and carried out the experiments. Prof. Dr. Ayman A. Gouda helped in check spelling, reducing the plagiarism, interpreting the data, reviewed the manuscript, and submitted the manuscript for publication.

\section{CONFLICTS OF INTEREST}

The authors confirm that this article content has no conflicts of interest.

\section{AUTHORS' FUNDING}

None.

\section{REFERENCES}

1. Kawamori R, Inagaki N, Araki E, Watada H, Hayashi N, Horie Y, et al. Linagliptin monotherapy provides superior glycaemi c control versus placebo or voglibose with comparable safety in Japanese patients with Type 2 diabetes: A randomized, placebo and active comparatorcontrolled, double-blind study. Diabetes Obes Metab 2012;14:348-57.

2. Jyothirmai N, Kumar MA, Nagaraju B. Novel UV and visible spectrophotometric methods for the analysis of empagliflozin a Type 2 diabetic drug in bulk and pharmaceutical formulations. J Afr 2016;3:177-87.

3. Raedler LA. Glyxambi (Empagliflozin/linagliptin): A dual-acting oral medication approved for the treatment of patients with Type 2 diabetes. Am Health Drug Benefits 2015;8:171-5.

4. Banik S, Karmakar P, Miah MA. Development and validation of a UV-spectrophotometric method for determination of vildagliptin and linagliptin in bulk and pharmaceutical dosage forms. Bangladesh Pharm J 2015; 18:163-8.

5. Sangeetha RK, Subashri T. Analysis of linagliptin in tablet dosage form by UV spectroscopy method, its derivatives and difference spectra. Euro J Pharm Med Res 2016;3:536-40.

6. Padmaja N, Veerabhadram G. Development and validation of analytical method for simultaneous estimation of empagliflozin and linagliptin in bulk drugs and combined dosage forms using UV-visible spectroscopy. Pharm Lett 2015;7:306-12.

7. Bassam MA. Development and validation of simple spectrophotometric and chemometric methods for simultaneous determination of empagliflozin and metformin: Applied to the recently approved pharmaceutical formulation. Spectrochim Acta Part A 2016;168:118-22.

8. Ayoub BM. UPLC simultaneous determination of empagliflozin, linagliptin and metformin. RSC Adv 2015;116:95703-9.

9. Maha FA, Omar AA, Miriam FA, Mariam MT. Pharmaceutical analysis of linagliptin and empagliflozin using LC-MS/MS. Pharma Chem 2016;8:186-9.

10. Madhusudhan P, Radhakrishna MR, Devanna N. RP-HPLC method 
development and validation for simultaneous determination of linagliptin and empagliflozin in tablet dosage form. Int Adv Res J Sci Eng Technol 2015;2:95-9.

11. Kavitha KY, Geetha G, Hariprasad R, Kaviarasu M. Development and validation of stability indicating RP-HPLC method for the simultaneous estimation of linagliptin and metformin in the pure and pharmaceutical dosage form. J Chem Pharm Res 2013;5:230-5.

12. Donepudi S, Achanta S, validated HPLC-UV method for simultaneous estimation of linagliptin and empagliflozin in human plasma. Int J Appl Pharm 2018;10:56-61.

13. Padmaja N, Veerabhadram G. Development and validation of a novel stability-indicating RP-HPLC method for the determination of empagliflozin in bulk and pharmaceutical dosage form. Int J Pharm Sci Res 2016;7:4523-30.

14. Godasu SK, Sreenivas SA. A new validated RP-HPLC method for the determination of metformin $\mathrm{HCl}$ and empagliflozin in bulk and pharmaceutical dosage and forms. Int J Pharm Sci Res 2017;8:2223-32.

15. Patil SD, Amurutkar SV, Chatpalliwar VA, Upasani CD. Development and validation of RP-HPLC method for empagliflozin and metformin HCL. J Innov Pharm Biol Sci 2017:4:185-9.

16. Sujatha K, Seshagirirao JV. A new RP-HPLC method for the estimation of linagliptin in tablet dosage forms. Indo Am J Pharm Res 2013;3:8376-81.

17. Badugu LR. A validated RP-HPLC method for the determination of linagliptin. Am J PharmaTech Res 2012;2:462-70.

18. Afzal SJ, Asif M, Khan PM. Validation of stability indicating high performance liquid chromatographic method for simultaneous determination of assay of linagliptin and metformin drugs in the pharmaceuticals tablet formulations using bupropion as a common internal standard. J Innov Pharm Biol Sci 2018;5:21-8.

19. Madhusudhan P, Reddy R, Deanna N. RPHPLC method development and validation for simultaneous determination of linagliptin and empagliflozin in tablet dosage form. Int Adv Res J Sci Eng Technol 2015;2:95-9.

20. Naazneen S, Sridevi A. Development and validation of stability indicating RP-HPLC method for simultaneous estimation of empagliflozin and linagliptin in tablet formulation. Pharm Lett 2016,8:57-65

21. Jayalaxmi, Rajesh T, Kumar GV. A validated RP- HPLC method for the simultaneous estimation of empagliflozin and linagliptin in its bulk and pharmaceutical dosage forms. Int J Chem Pharm Sci 2016;4:634-40.

22. Jyothirmai N, Begum KMD, Supriya P. Novel stability indicating RPHPLC method for the simultaneous estimation of empagliflozin and linagliptin in bulk and pharmaceutical formulations. J Atoms Mol 2016;6:977-86.

23. Bakshi A, Mounika A, Bhutada S, Raju MB. Simultaneous estimation of empagliflozin and linagliptin by RP-HPLC method. World J Pharm Pharm Sci 2018;7:1062-71

24. Shyamala, Nirmala K, Mounika J, Nandini B. Validated stability-indicating RP-HPLC method for determination of empagliflozin. Pharm Lett 2016;8:457-64.

25. El-Bagary RI, Elkady EF, Ayoub BM. Liquid chromatographic determination of linagliptin in bulk, in plasma and in its pharmaceutical preparation. Int J Biomed Sci 2012;8:209-14

26. ICH Guidelines for Validation of Analytical Procedures: Text and Methodology Q2 (R1). Geneva: ICH; 2005. p. 1-14 